\title{
KESESUAIAN ELEMEN RANCANG KAWASAN PENDIDIKAN KOTA BARAT DALAM MENDUKUNG KOTA SURAKARTA SEBAGAI KOTA RAMAH ANAK
}

\author{
Muhammad Yudha Faizal', Galing Yudana1, Paramita Rahayu' \\ ${ }^{1}$ Program Studi Perencanaan Wilayah dan Kota Fakultas Teknik Universitas Sebelas Maret Surakarta
}

\begin{abstract}
Abstrak
Tingginya daya tarik sekolah pada pusat perkotaan menjadikan jumlah anak - anak yang beraktivitas pada kawasan tersebut cukup tinggi. Konsep kawasan ramah anak pada kawasan pendidikan diperlukan untuk mengakomodasi pemenuhan hak anak pada setiap aktivitas anak - anak di perkotaan. Penelitian ini bertujuan untuk melihat kesesuain elemen rancang menggunakan indikator kawasan ramah anak. Penelitian mengambil studi kasus pada kawasan Kota Barat Surakarta sebagai kawasan dengan dominasi aktivitas pendidikan. Kawasan ini dipilih karena mampu menggambarkan aktivitas tertinggi anak - anak di Kota Surakarta, dimana Surakarta merupakan salah satu kota percontohan program Kota Layak Anak di Indonesia. Metode pengumpulan data yang digunakan dalam penelitian ini adalah observasi dan wawancara. Data yang didapatkan kemudian dianalisis menggunakan teknik analisis skoring dan statistik deskriptif. Hasil penelitian ini menunjukkan tingkat kesesuaian elemen rancang pada kawasan sebesar $54 \%$. Elemen rancang kawasan Kota Barat yang sudah termasuk dalam kategori sesuai $>50 \%$ adalah tata bangunan dan ruang terbuka, elemen rancang yang memiliki tingkat kesesuaian sebesar $50 \%$ adalah tata guna lahan, sirkulasi, kualitas lingkungan, dan signage, sedangkan yang tergolong tidak sesuai adalah pedestrian. Ditinjau dari aspek kawasan ramah anak, aspek keamanan menjadi aspek yang paling tidak terpenuhi. Berdasarkan analisis lebih lanjut, ditemukan bahwa kawasan kota barat belum menjadi kawasan khusus yang diatur untuk mengakomodasi aktivitas pendidikan anak - anak.
\end{abstract}

Kata kunci: Kawasan Ramah Anak, Elemen Rancang, Kawasan Pendidikan

\begin{abstract}
The high attractiveness of schools in urban centers makes the number of children who move on the area is quite high. The concept of child-friendly district in educational areas is needed to accommodate the fulfillment of children's rights in every activity of children in urban areas. This study aims to see the suitability of design elements using child friendly area indicators. The study took a case study on the Kota Barat District on Surakarta as an area with the dominance of educational activity. This area was chosen because it is able to describe the highest activity of children in Surakarta City, where Surakarta is one of the pilot city of Kota Layak Anak program in Indonesia. The results of this study indicate the suitability level of design elements in the district by $54 \%$. Elements of the design of the Kota Barat district that is included in the category of $>50 \%$ is open space, building and mass building, design elements that have a level of suitability of $50 \%$ is land use, circulation, environmental quality, and signage, while the not suitable is pedestrian. Viewed from the aspect of child-friendly district, the security aspect becomes the most unfulfilled aspect. Based on further analysis, it was found that the western city area has not yet become a special area that is set to accommodate children's educational activities.
\end{abstract}

Keywords: Child Friendly District, Urban Design Element

\section{PENDAHULUAN}

Kualitas pendidikan merupakan faktor utama yang paling berpengaruh sebagai daya tarik masyarakat dalam menentukan sekolah bagi anak-anak (Andryana, 2009). Kondisi ini menjadikan Kota Surakarta sebagai pusat perkotaan bagi wilayah di sekitarnya, memiliki daya tarik yang tinggi sebagai tujuan anak-anak dalam bersekolah (Soebagiyo, 2007). Keberadaan penduduk yang tergolong dalam usia anak-anak disikapi oleh Pemerintah Kota Surakarta melalui program Kota Layak Anak yang tertuang dalam Peraturan Walikota Surakarta Nomor 3B tahun 2013. Program ini bertujuan untuk menjamin terpenuhinya hak anak dalam kehidupan kota secara khusus.

Perwujudan Kota Ramah Anak secara umum memiliki 9 tahapan (Nour, 2013). Dalam tahapan tersebut Kota Surakarta sudah berada pada tahap 4, yaitu terbentuknya institusi atau lembaga khusus yang mengakomodasi hak anak dalam lingkup yang berjenjang. Tahap ini merupakan tahap lanjutan dari tahap 3 yaitu perwujudan hak anak dalam 
strategi dan rencana aksi kota. Untuk itu, penelitian ini bertujuan untuk melihat kesesuaian yang dilakukan oleh Kota Surakarta dalam implementasi hak anak pada tahap strategi dan rencana aksi kota. Dengan mengetahui kesesuaian pada tahap ini, maka dapat tergambar juga bagaimana kondisi Kota Surakarta dalam mewujudkan Kota Ramah Anak secara keseluruhan.

Untuk mengetahui kesesuaian pada tahap strategi dan rencana aksi kota yang sudah berjalan, maka penelitian difokuskan pada kesesuaian elemen rancang yang melihat area dengan jumlah aktivitas anak - anak terpadat. Kawasan Kota Barat yang berlokasi di area pusat Kota Surakarta menjadi kawasan yang dipilih karena memiliki tujuh sekolah, dan tiga dari tujuh sekolah tersebut merupakan sekolah unggulan. Terdapat juga dua pembangunan sekolah baru yang berada dalam kawasan. Selain sekolah, aktivitas yang ada pada sekeliling sekolah memiliki kaitan dengan aktivitas pendidikan, sehingga anak - anak tidak hanya beraktivitas di dalam sekolah namun juga pada seluruh bagian kawasan.

Semakin tingginya aktivitas anak - anak yang akan muncul di kawasan, maka kebutuhan akan keberadaan kawasan yang mampu mengakomodasi aktivitas anak akan semakin tinggi. Perlu adanya penelitian yang melihat keterkaitan konsep kawasan ramah anak pada kawasan pendidikan yang ada di Kota Surakarta. Dengan melihat Kawasan Kota Barat sebagai sampel kawasan pendidikan, maka penelitian ini juga dapat disesuaikan dengan kawasan pendidikan lain yang ada di Kota Surakarta.

\section{KAJIAN TEORI}

Dalam menentukan elemen rancang yang akan berfungsi sebagai variabel, maka dibutuhkan pemilihan berdasarkan literatur yang ada dengan kebutuhan pada konteks kawasan sebagai kawasan pendidikan. Elemen rancang didasarkan pada dua literatur, yaitu berdasarkan pada Pedoman RTBL (Kementerian PU, 2007) dan elemen rancang (Shirvani, 1997). Elemen rancang yang didapatkan berdasarkan dua literatur tersebut adalah tata guna lahan, tata bangunan, sirkulasi pergerakan, ruang terbuka, kualitas lingkungan, pedestrian, dan signage. 7 elemen rancang ini dijabarkan dalam tabel berikut,

Tabel 1. Definisi Operasional Variabel

\begin{tabular}{|l|l|l|}
\hline No & Variabel & Definisi \\
\hline 1 & Tata Guna Lahan & $\begin{array}{l}\text { denah dua dimensi sebagai tempat yang akan dibangun bangunan sesuai dengan } \\
\text { fungsi dari lahan yang sudah ditetapkan, termasuk intensitas penggunaan suatu } \\
\text { lahan. }\end{array}$ \\
\hline 2 & Tata Bangunan & $\begin{array}{l}\text { hasil dari keberadaan bangunan gedung dan lingkungannya, meliputi berbagai } \\
\text { aspek termasuk pembentukan karakter fisik lingkungan, besaran, dan konfigurasi } \\
\text { dari elemen-elemen bangunan. }\end{array}$ \\
\hline 3 & Sirkulasi Pergerakan & $\begin{array}{l}\text { elemen yang dapat membentuk dan mengendalikan pola kegiatan, meliputi sistem } \\
\text { transportasi, pedestrian, tempat transit, dan ruang parkir. }\end{array}$ \\
\hline 4 & Ruang Terbuka & $\begin{array}{l}\text { desain tata hijau yang mampu membentuk karakter dan berperan secara ekologis, } \\
\text { rekreatif, dan estetis bagi lingkungan serta mudah diakses oleh publik. Dapat } \\
\text { berupa lapangan, jalan, sempadan sungai, green belt, dan taman. }\end{array}$ \\
\hline 5 & Kualitas Lingkungan & $\begin{array}{l}\text { rekayasa elemen kawasan sehingga tercipta kawasan dengan sistem lingkungan } \\
\text { yang informatif, berkarakter, dan berorientasi tertentu. }\end{array}$ \\
\hline 6 & Pedestrian & $\begin{array}{l}\text { elemen yang berkaitan langsung dengan aktivitas pejalan kaki dan harus } \\
\text { disesuaikan dengan lingkungan dan pola-pola aktivitas }\end{array}$ \\
\hline 7 & Signage & $\begin{array}{l}\text { berkaitan dengan keberadaan petunjuk arah jalan, rambu, dan media iklan yang } \\
\text { berpengaruh langsung pada visualisasi kawasan. }\end{array}$ \\
\hline
\end{tabular}

Sumber : Shirvani (1997) dan KemenPU (2007)

Sebagai dasar dalam menentukan indikator kesesuaian kawasan ramah anak pada setiap elemen rancang, maka diperlukan klasifikasi aspek dalam menilai kawasan ramah anak. Berdasarkan sintesa dari berbagai literatur mengenai kawasan ramah anak, yaitu Diyanti (2014), UNICEF (2016), Wessells (2013), Rothman (2016), dan Malone (2013) maka didapatkan empat aspek kawasan ramah anak yaitu aspek keamanan, aspek kenyamanan, aspek kesehatan, dan aspek stimulasi. Setiap elemen rancang akan dilihat berdasarkan empat aspek tersebut, berikut tabel kesesuaian aspek berdasarkan berbagai literatur.

Aspek keamanan merupakan aspek yang mampu memberikan rasa aman bagi anak - anak dalam beraktivitas di dalam kawasan.Termasuk di dalamnya adalah perlindungan dari bencana, kriminalitas, dan gangguan lain (UNICEF, 
2016). Pemenuhan aspek keamanan menjadi penting karena hal ini menjadi jaminan dari keberlangsungan aktivitas anak - anak di kawasan. Untuk itu, kunci dari terwujudnya lingkungan yang aman bagi anak - anak adalah adanya pengawasan dan jaminan keselamatan (Diyanti, 2014).

Tabel 2. Literatur Aspek Keamanan

\begin{tabular}{|l|l|l|l|}
\hline No & Variabel & Indikator & Sumber \\
\hline 1 & Tata Guna Lahan & $\begin{array}{l}\text { Ada guna lahan permukiman } \\
\text { berkepadatan tinggi }\end{array}$ & (Rothman, et al., 2016) \\
\hline 2 & Tata Bangunan & $\begin{array}{l}\text { Tidak ada bangunan yang menghalangi } \\
\text { pengawasan aktivitas anak }\end{array}$ & (Diyanti, 2014) \\
\hline 3 & Sirkulasi Pergerakan & Arus kendaraan bermotor satu arah & (Rothman, et al., 2016) \\
\hline 4 & Ruang Terbuka & $\begin{array}{l}\text { Tidak ada objek yang menghalangi } \\
\text { aktivitas di ruang terbuka }\end{array}$ & (Diyanti, 2014) \\
\hline 5 & Kualitas Lingkungan & $\begin{array}{l}\text { Tidak ada rancangan lingkungan yang } \\
\text { berbahaya }\end{array}$ & (Diyanti, 2014) \\
\hline 6 & Pedestrian & Tidak memiliki furniture berbahaya & (Diyanti, 2014) \\
(Malone, 2013)
\end{tabular}

Aspek kenyamanan berperan dalam mempengaruhi rasa nyaman anak - anak selama beraktivitas di kawasan. Diperlukan 4 hal untuk memenuhi aspek kenyamanan, yaitu kenyamanan visual, therma, spasial, dan akustik (Diyanti, 2014). Faktor kenyamanan juga banyak dipertimbangkan dengan keberadaan jalur khusus untuk menunjang sirkulasi anak - anak dalam suatu kawasan (Malone, 2013)

Tabel 3. Kesesuaian Aspek Kenyamanan

\begin{tabular}{|l|l|l|l|}
\hline No & Variabel & Indikator & Sumber \\
\hline 1 & Tata Guna Lahan & Memiliki KDB dan KLB yang relatif rendah & (Diyanti, 2014) \\
\cline { 3 - 4 } & & $\begin{array}{l}\text { Terdapat open space dan dapat diakses } \\
\text { untuk kegiatan anak anak }\end{array}$ & (Diyanti, 2014) \\
\hline 2 & Tata Bangunan & Bangunan tidak berukuran massif & (Diyanti, 2014) \\
\cline { 3 - 4 } & Sampu mereduksi polusi suara dari luar & (Malone, 2013) \\
\hline 3 & Sirkulasi Pergerakan & $\begin{array}{l}\text { Terdapat jalur khusus yang } \\
\text { mengakomodasi segala sirkulasi anak - } \\
\text { anak. }\end{array}$ & (Malone, 2013) \\
\hline 4 & Ruang Terbuka & $\begin{array}{l}\text { Terdapat pagar berupa vegetasi atau } \\
\text { buatan untuk memecah polusi suara dan } \\
\text { pembentuk suasana }\end{array}$ & (Diyanti, 2014) \\
\hline 5 & Kualitas Lingkungan & $\begin{array}{l}\text { Terdapat vegetasi dan memiliki karakter } \\
\text { suasana tertentu }\end{array}$ & (Diyanti, 2014) \\
\hline 6 & Pedestrian & $\begin{array}{l}\text { Ada material alami dan mampu } \\
\text { meneduhkan }\end{array}$ & (Malone, 2013) \\
\hline 7 & Signage & $\begin{array}{l}\text { Terdapat tanda yang menunjukan lokasi - } \\
\text { lokasi anak dapat beraktivitas seperti } \\
\text { bermain, makan, dan belajar }\end{array}$ & (Diyanti, 2014) \\
\hline
\end{tabular}

Aspek kesehatan merupakan pembahasan terkait suatu kondisi yang terbebas dari gangguan jasmani, rohani, maupun sosial dengan usaha pencegahan dan pengobatan pada gangguan tersebut, khususnya yang disebabkan oleh faktor lingkungan (Diyanti, 2014). Aspek kesehatan juga melihat mengenai kemampuan kawasan dalam memicu peningkatan kesehatan melalui intervensi yang optimal seperti memicu aktif berjalan kaki, dan komunitas penggiat kesehatan (Audrey \& Batista, 2015) 
Tabel 4. Kesesuaian Aspek Kesehatan

\begin{tabular}{|c|c|c|c|}
\hline No & Variabel & Indikator & Sumber \\
\hline 1 & Tata Guna Lahan & $\begin{array}{l}\text { Terdapat aktivitas antar guna lahan yang } \\
\text { saling terkait }\end{array}$ & (Audrey \& Batista-Ferrer, 2015) \\
\hline 2 & Tata Bangunan & $\begin{array}{l}\text { Tidak terdapat material berbahaya dan } \\
\text { berpotensi mengeluarkan racun }\end{array}$ & (Diyanti, 2014) \\
\hline 3 & Sirkulasi Pergerakan & $\begin{array}{l}\text { Ada sirkulasi pergerakan aktif yang } \\
\text { dilakukan dengan berjalan kaki atau } \\
\text { bersepeda }\end{array}$ & (Audrey \& Batista-Ferrer, 2015) \\
\hline \multirow[t]{2}{*}{4} & \multirow[t]{2}{*}{ Ruang Terbuka } & Tidak terdapat material yang berbahaya & (Diyanti, 2014) \\
\hline & & $\begin{array}{l}\text { Mampu mengakomodasi dan memicu } \\
\text { untuk beraktivitas fisik. }\end{array}$ & (Audrey \& Batista-Ferrer, 2015) \\
\hline 5 & Kualitas Lingkungan & $\begin{array}{l}\text { Terpenuhi air bersih dan sanitasi yang } \\
\text { tidak bermasalah }\end{array}$ & (UNICEF, 2006) \\
\hline 6 & Pedestrian & $\begin{array}{l}\text { Terdapat bangku untuk istirahat dan } \\
\text { didesain sesuai kebutuhan anak }\end{array}$ & (UNICEF, 2006) \\
\hline 7 & Signage & $\begin{array}{l}\text { Terdapat rambu larangan narkoba, alkohol, } \\
\text { dan rokok. }\end{array}$ & (UNICEF, 2006) \\
\hline
\end{tabular}

Aspek stimulan melihat kemampuan kawasan dalam memicu aktivitas pada anak - anak. Anak - anak cenderung menyukai aktivitas olahfisik, bermain, dan berinteraksi dengan alam (Malone, 2013). Kawasan juga dituntut untuk mampu menghilangkan stimulant negative seperti keberadaan reklame yang berkaitan dengan hal buruk bagi anak, misalnya rokok, alkohol, atau narkoba (Lam, 1998).

Tabel 5. Kesesuaian Aspek Stimulan

\begin{tabular}{|l|l|l|l|}
\hline No & Variabel & Indikator & Sumber \\
\hline 1 & Tata Guna Lahan & $\begin{array}{l}\text { Terdapat open space yang mampu } \\
\text { mengakomodasi aktivitas olahraga } \\
\text { terstruktur }\end{array}$ & (Malone, 2013) \\
\hline 2 & Tata Bangunan & $\begin{array}{l}\text { Memiliki variasi bentuk yang beragam, } \\
\text { tidak satu jenis. }\end{array}$ & (Diyanti, 2014) \\
\hline 3 & Sirkulasi Pergerakan & $\begin{array}{l}\text { Memiliki beragam alternatif pergerakan } \\
\text { anak - anak. Tidak memiliki satu pola } \\
\text { apabila melakukan sirkulasi antar pusat } \\
\text { aktivitas }\end{array}$ & (Malone, 2013) \\
\hline 4 & Ruang Terbuka & $\begin{array}{l}\text { Memiliki variasi bentuk dan tekstur, } \\
\text { sehingga bukan menjadi ruang terbuka } \\
\text { yang terkesan kaku. }\end{array}$ & (Diyanti, 2014) \\
\hline 5 & Kualitas Lingkungan & $\begin{array}{l}\text { Jalan di sekitar mampu mengakomodasi } \\
\text { aktivitas bersosialisasi }\end{array}$ & (Malone, 2013) \\
\hline 6 & Pedestrian & $\begin{array}{l}\text { Memiliki unsur way-finding dan kreatifas } \\
\text { seperti ornamen unik, penanda, dan } \\
\text { desain yang beragam }\end{array}$ & (Malone, 2013) \\
\hline 7 & Signage & $\begin{array}{l}\text { Tidak terdapat reklame atau baliho } \\
\text { tentang rokok, alkohol, ataupun hal yang } \\
\text { berbahaya bagi kesehatan anak. }\end{array}$ & (Lam, Chung, Betson, Wong, \& \\
\hline
\end{tabular}

\section{METODE PENELITIAN}

\subsection{PENDEKATAN DAN JENIS PENELITIAN}

Penelitian menggunakan pendekatan deduktif, yaitu dengan merumuskan kesimpulan umum, kemudian menjabarkan kedalam poin - poin khusus. Penelitian dilakukan dengan menguji tingkat kesesuaian kawasan kota barat sebagai kawasan pendidikan dengan mengacu konsep ramah anak. Jenis penelitian ini adalah penelitian kuantitatif, sehingga sebelum melakukan penelitian dilakukan penyusunan secara detail indikator-indikator yang termasuk dalam 
kriteria kawasan ramah anak. Indikator yang digunakan terbagi ke dalam 4 aspek kawasan ramah anak, yaitu keamanan, kenyamanan, kesehatan dan stimulant. Setiap aspek memiliki 7 indikator yang didapatkan berdasarkan elemen rancang kawasan. Setiap hasil dari penilaian indikator didapatkan dari sumber-sumber yang valid dan parameter yang terukur secara sistematis, sehingga tidak ada subjektifitas peneliti dalam menentukan nilai akhir. (Sugiyono, 2013)

\subsection{TEKNIK PENGUMPULAN DATA}

Teknik pengumpulan data yang digunakan untuk memperoleh data sekunder adalah survey pada instansi terkait yang memiliki data mengenai persil lahan yang dimiliki oleh Bappeda Kota Surakarta dan jaringan air bersih yang dimiliki PDAM Kota. Sedangkan untuk data primer, dilakukan melalui observasi pada elemen-elemen rancang di kawasan. Elemen rancang yang menjadi objek observasi adalah aktivitas lahan, bangunan, sirkulasi, ruang terbuka, lingkungan, pedestrian, dan signage. Dalam menggunakan metode observasi, cara yang paling efektif adalah melengkapinya dengan sebuah blangko pengamatan sebagai instrumen (Arikunto, 2011). Tabel blangko yang akan digunakan untuk survey observasi dibedakan berdasarkan penggal jalan di Kawasan Kota Barat.

\subsection{TEKNIK ANALISIS DATA}

Teknik analisis data yang digunakan dimulai dengan analisis skoring berdasarkan indikator yang tercantum dalam 4 aspek, yaitu aspek keamanan, aspek kesehatan, aspek kenyamanan, dan aspek stimulasi. Skala yang digunakan untuk isian penilaian adalah Skala Guttman. Skala ini mempunyai ciri penting yaitu merupakan skala kumulatif dengan mengukur satu dimensi saja dari satu variabel yang multidimensi, sehingga skala ini termasuk mempunyai sifat unidimensional. Dalam penelitian ini, peneliti menggunakan Skala Guttman untuk menentukan nilai dari setiap variabel berdasar aspek - aspek kawasan ramah anak. Setiap variabel dalam satu aspek memiliki nilai maksimal 1, sehingga total penilaian dalam satu variabel di semua aspek memiliki nilai maksimal 4. Setiap hasil akan dideskripsikan untuk menunjukkan kesesuaian variabel terhadap konsep (Badan Pusat Statistik, 2010).

\section{HASIL DAN PEMBAHASAN}

\subsection{POSISI KOTA SURAKARTA DALAM PERKEMBANGAN KOTA RAMAH ANAK}

Perwujudan dalam mencapai kota ramah anak di Indonesia dimulai dengan pencanangan program Kota Layak Anak oleh Kementerian Pemberdayaan Perempuan dan Perlindungan Anak (KPPPA). Kota Surakarta telah mencanangkan program Kota Layak Anak yang dituangkan ke dalam Peraturan Walikota nomor 3B Tahun 2013. Kebijakan tersebut disusun menjadi sebuah pedoman yang bertujuan untuk meningkatkan perwujudan hak anak dalam pembangunan kota. Peraturan ini juga menjadi tindak lanjut dari Peraturan Menteri PPA nomor 12 Tahun 2011 tentang indikator kota layak anak. Berdasarkan indikator penilaian tersebut, KPPPA menganugerahkan predikat Nindya di tahun 2013 dan menjadikan Kota Surakarta sebagai percontohan program kota layak anak.

Melihat konsep perwujudan kota ramah anak, terdapat 9 langkah untuk mencapai predikat sebagai kota ramah anak (Nour, 2013). Berdasarkan langkah tersebut, perwujudan kota ramah anak yang dituangkan dalam Peraturan Walikota nomor 3B tahun 2013 telah sampai pada tahap ke-4. Pada tahap pertama dan kedua kota ramah anak, Kota Surakarta dapat dikatakan telah melaluinya. Tahap pertama yaitu adanya kesadaran akan pentingnya partisipasi anak - anak dalam pengambilan keputusan. Kota Surakarta dianggap telah memenuhi dengan indikasi yaitu dengan dicanangkannya program Kota Layak Anak pada tahun 2004 melalui tagline Solo Kota Layak Anak. Tahap kedua pada perumusan kebijakan legal telah diwujudkan dalam Peraturan Walikota nomor 3B tahun 2013 dan Peraturan Daerah Kota Surakarta nomor 4 tahun 2012 tentang Perlindungan Anak.

Tahap ke-3 yaitu penyertaan hak anak pada strategi dan aksi pembangunan, wujud nyata dapat terlihat pada kondisi fisik Kota Surakarta dalam kaitannya dengan akomodasi hak anak. Hal ini sudah diterapkan oleh Kota Surakarta melalui berbagai tingkatan rencana tata ruang. Kota Surakarta telah memiliki rencana tata ruang wilayah perkotaan, rencana 
detail tata ruang kota, hingga rencana tata bangunan dan lingkungan pada kawasan-kawasan strategis kota. Perwujudan strategi dan rencana aksi pembangunan juga telah berada pada tahap implementasi, sehingga pada beberapa kawasan kota sudah terlihat ada perwujudan fisik dari strategi dan rencana aksi yang telah ditetapkan.

Pada tahap ke-4, perwujudan lembaga khusus dalam mengakomodasi tujuan kota ramah anak telah dilakukan dan diatur dalam Perwali nomor 3B tahun 2013. Kota Surakarta mewujudkannya dalam pembentukan Forum Anak yang bertujuan untuk menyalurkan aspirasi, keinginan, dan kebutuhan anak ke dalam musyawarah pembangunan. Secara tingkatan, forum anak memiliki 2 tingkatan yaitu pada tingkat kota dan kecamatan. Pada tingkat kelurahan, forum anak terintegrasi dalam lembaga masyarakat yang ada di kelurahan.

Berdasarkan penjabaran diatas, maka posisi penelitian ini berada pada tahap ke-5. Yaitu tahap evaluasi dan penilaian terhadap implementasi berbagai rencana pemenuhan hak anak. Evaluasi kesesuaian melihat pada tahap 3 , khususnya pada implementasi fisik rencana melalui rancang sebuah kawasan yang memiliki dominasi aktivitas anak anak. Berdasarkan hasil analisis pada kawasan pendidikan kota barat yang memiliki banyak aktivitas oleh anak - anak, tingkat kesesuaian berdasarkan indikator kawasan ramah anak secara keseluruhan memiliki kesesuaian sebesar $54 \%$. Kesesuaian ini didapatkan berdasarkan 4 aspek kriteria kawasan ramah anak yaitu keamanan, kenyamanan, kesehatan, dan stimulasi. Kota Surakarta belum berada pada tahap selanjutnya karena masih belum mengalokasikan secara khusus sumber daya kota dalam usaha implementasi hak anak.

\subsection{KAWASAN KOTA BARAT BAGI KOTA SURAKARTA}

Secara khusus, Kota Surakarta tidak memiliki peraturan yang mengatur tentang adanya kawasan pendidikan. Secara administratif, kota barat terdapat pada Kelurahan Mangkubumi dalam Kecamatan Laweyan. Apabila meninjau secara kawasan fungsional yang ditetapkan berdasarkan Rencana Detail Tata Ruang Kota Surakarta (RDTRK), kawasan ini terbagi menjadi dua Bagian Wilayah Perencanaan (BWP), yaitu BWP 2 dan 6. Atas dasar ini dapat dilihat bahwa Kawasan Pendidikan Kota Barat bukan merupakan sebuah kawasan khusus yang diatur perkembangannya dalam strategi pembangunan kota.

Melihat secara fungsional kawasan kota barat dalam aktivitas pendidikan, kawasan ini memiliki 7 sarana pendidikan yang terbagi dalam 1 TK, 4 SD, dan 2 SMP. Berdasarkan observasi juga ditemukan rencana pembangunan 1 SMP dan 1 SMA oleh yayasan swasta di kawasan ini. Sebagai pendukung aktivitas pendidikan, dalam kawasan ini juga terdapat lapangan olahraga, penyedia jasa bimbingan belajar, dan tempat makan. Setiap titik aktivitas ini memiliki keterkaitan pengguna dan pergerakan aktif yang membentuk pola aktivitas ruang. Terbentuknya pola aktivitas ruang ini menjadikan kawasan kota barat menjadi sebuah kawasan fungsional dengan dominasi aktivitas pendidikan.

Sarana pendidikan berupa sekolah yang mendominasi fungsi kawasan secara teoritis memiliki jangkauan pelayanan lingkungan hingga kota. Namun dalam fakta lapangannya, keberadaan sekolah dalam kawasan ini memiliki pengguna yang berasal dari lingkup regional. Khususnya pada sekolah yang dikelola oleh pihak swasta, sekolah ini tidak terikat dengan pembatasan pelayanan bagi masyarakat luar kota. Hal ini juga didukung Andryana (2009) tentang faktor yang mempengaruhi pemilihan sekolah oleh orang tua. Hasil penelitian tersebut menggambarkan bahwa orang tua di Indonesia cenderung memilih sekolah untuk anaknya di kota yang dinilai memiliki kualitas pendidikan lebih baik.

Status Kota Surakarta sebagai pusat aktivitas perkotaan bagi wilayah sekitarnya dan keberadaan sarana pendidikan dari mulai tingkat TK hingga SMA, menjadikan pelayanan sarana pendidikan di kota ini memiliki jangkauan hingga skala regional. Hal ini menjadikan posisi kawasan kota barat tidak hanya berfungsi bagi Kota Surakarta secara khusus, namun juga menjangkau kawasan sekitarnya. Kondisi ini menjadikan jumlah anak - anak yang ada dalam kawasan Kota Barat sebagai mayoritas pengguna kawasan.

Skala pelayanan regional dan jumlah anak yang menjadi mayoritas membutuhkan pendekatan pengembangan ruang yang lebih khusus. Pengembangan dalam skala lingkungan administratif tidak tepat dilakukan untuk memenuhi kebutuhan pengguna ruang. Sudah seharusnya Kota Surakarta menggunakan pendekatan pengembangan kawasan 
khusus bagi Kawasan Kota Barat sebagai Kawasan Pendidikan. Pengembangan secara khusus dengan berlandaskan pada Kawasan Ramah Anak bertujuan untuk membantu mewujudkan Kota Surakarta sebagai Kota Layak Anak

\subsection{MATRIKS HASIL ANALISIS KESESUAIAN ELEMEN RANCANG}

Setiap indikator yang sudah dianalisis dan memiliki nilai akan dimasukkan ke dalam tabel kesesuaian. Setiap indikator yang terpenuhi bernilai 1 sedangkan yang tidak bernilai 0 . Berikut tabel matriks kesesuaian.

Tabel 6 Matriks Kesesuaian

\begin{tabular}{|c|c|c|c|c|c|}
\hline Variabel & $\begin{array}{l}\text { Aspek } \\
\text { Keamanan }\end{array}$ & $\begin{array}{l}\text { Aspek } \\
\text { Kenyamanan }\end{array}$ & $\begin{array}{l}\text { Aspek } \\
\text { Kesehatan }\end{array}$ & $\begin{array}{l}\text { Aspek } \\
\text { Stimulasi }\end{array}$ & Total Skor \\
\hline Tata Guna Lahan & 0 & 0 & 1 & 1 & $2 / 4 \quad(50 \%)$ \\
\hline Tata Bangunan & 1 & 1 & 1 & 1 & $4 / 4 \quad(100 \%)$ \\
\hline Sirkulasi & 0 & 0 & 1 & 1 & $2 / 4 \quad(50 \%)$ \\
\hline Ruang Terbuka & 0 & 1 & 1 & 1 & $\begin{array}{ll}3 / 4 & (75 \%) \\
\end{array}$ \\
\hline Lingkungan & 1 & 0 & 1 & 0 & $\begin{array}{ll}2 / 4 & (50 \%)\end{array}$ \\
\hline Pedestrian & 0 & 0 & 0 & 0 & $(0 \%)$ \\
\hline Signage & 0 & 1 & 0 & 1 & $2 / 4 \quad(50 \%)$ \\
\hline Total & $2 / 7 \quad(29 \%)$ & $3 / 7 \quad(43 \%)$ & $5 / 7 \quad(71 \%)$ & $\begin{array}{ll}5 / 7 & (71 \%)\end{array}$ & $15 / 28(54 \%)$ \\
\hline
\end{tabular}

Sumber : Hasil Analisis

Secara keseluruhan, kesesuaian elemen rancang pada kawasan penelitian terhadap indikator kawasan ramah anak sebesar $15 / 28$ atau $54 \%$ yang mengindikasikan bahwa kesesuaian kawasan mendekati sesuai. Dilihat dari segi aspek, aspek kesehatan dan aspek stimulasi memiliki tingkat kesesuaian yang tergolong tinggi. Ditinjau dari variabelnya, variable tata bangunan memenuhi semua aspek kawasan ramah anak. Variable ruang terbuka juga tergolong tinggi $(75 \%)$ jika dibandingkan variable lain. Sedangkan variable pedestrian, memiliki nilai kesesuaian 0 yang berarti tidak ada aspek dari kawasan ramah anak yang terpenuhi oleh variable ini.

a. Tata Guna Lahan

Elemen Tata Guna Lahan memiliki nilai kesesuaian 50\%. Ketidaksesuaian pada aspek keamanan disebabkan karena sekolah tidak ditempatkan pada area permukiman dengan kepadatan tinggi. Kondisi ini dapat dianggap sebagai limitasi pengembangan karena letak kawasan yang berada di pusat kota, sehingga jumlah bangunan termasuk sedikit namun berukuran besar. Untuk menanganinya maka diperlukan ubahan pada elemen lain untuk memberikan dampak keamanan yang sama seperti pada area berkepadatan bangunan tinggi.

Sedangkan ketidaksesuaian pada aspek kenyamanan melihat pada tutupan lahan bangunan sekolah. Secara rinci, terdapat 2 dari 7 sekolah yang tidak memenuhi ketentuan tutupan lahan. SD Muhammadiyah PK cenderung jauh dari kenyamanan karena nilainya mendekati tutupan lahan 100\%, sedangkan SDN 16 Mangkubumen memiliki tutupan lahan yang mendekati sesuai. Secara tata bangunan ketidaksesuaian tutupan lahan ini dapat digantikan manfaatnya degan pendekatan elemen lain yang juga bertujuan menimbulkan kenyamanan.

\section{b. Tata Bangunan}

Elemen tata bangunan pada kawasan kota barat mampu memenuhi setiap aspek kawasan ramah anak dengan nilai $100 \%$. Tata bangunan pada kawasan memenuhi setiap indikator seperti ukuran bangunan yang tidak tergolong massif, memiliki kemampuan reduksi polusi suara yang baik, tidak memiliki bahan berbahaya dan beracun, dan memiliki variasi bentuk dan ukuran. Hal ini menandakan elemen tata bangunan pada kawasan sudah memenuhi kriteria penyusun kawasan ramah anak. Oleh karena itu dalam pengembangannya, elemen ini dapat diberi prioritas terendah.

\section{c. Sirkulasi Pergerakan}

Elemen sirkulasi memenuhi aspek kesehatan dan stimulasi, sedangkan tidak memenuhi pada aspek keamanan dan kenyamanan dengan nilai kesesuaian $50 \%$. Ketidaksesuaian pada aspek keamanan disebabkan terdapat sekolah yang memiliki pintu gerbang pada jalur dua arah, hal ini dianggap berbahaya bagi keamanan terlebih arus dua arah terdapat pada jalan raya dengan arus yang tergolong tinggi. Ketidaksesuaian pada aspek kenyamanan disebabkan oleh tidak adanya jalur khusus yang mengakomodasi keperluan mobilitas anak dalam kawasan. Dalam pemetaan di lapangan, kebutuhan jalur khusus ini berada pada jalan lingkungan utama dimana arus kendaraan tergolong tinggi. Untuk meningkatkan kenyamanan, maka dibutuhkan penunjuk atau jalur yang digunakan sebagai penanda untuk anak - anak dalam melakukan mobilitas. 


\section{d. Ruang Terbuka}

Elemen ruang terbuka memenuhi aspek kenyamanan, kesehatan, dan stimulasi, sedangkan pada aspek keamanan elemen ini tidak memenuhi sehingga elemen ruang terbuka memiliki nilai kesesuaian $75 \%$. Ketidaksesuaian pada aspek keamanan disebabkan kemampuan ruang terbuka dalam hal mengakomodasi keperluan pengawasan yang terhalang oleh objek. Pedagang menutup pagar yang berkisi dengan spanduk ataupun gerobak, sehingga aktivitas di dalam ruang terbuka tidak bisa diawasi dari luar. Seharusnya pedagang tidak menutupi kisi pagar dengan material yang solid, untuk itu dapat dikeluarkan peraturan penataan aktivitas pedagang. Selain itu, dapat juga dilakukan relokasi untuk mengembalikan fungsi trotoar.

\section{e. Kualitas Lingkungan}

Elemen kualitas lingkungan memenuhi aspek keamanan dan kesehatan, sedangkan tidak memenuhi pada elemen kenyamanan dan stimulasi sehingga memiliki nilai kesesuaian sebesar $50 \%$. Ketidaksesuaian pada aspek kenyamanan disebabkan kurangnya vegetasi yang dibutuhkan untuk membentuk karakter suasana, khususnya pada area area inti yang dilalui oleh anak - anak. Keberadaan vegetasi hanya berada pada sepanjang pedestrian dan area di sekitar sekolah, sedangkan apabila dilihat berdasarkan sirkulasi pergerakan anak maka dapat terlihat area area yang masih belum memiliki vegetasi. Ketidaksesuaian pada aspek stimulasi disebabkan kemampuan jalan yang dilalui oleh anak anak untuk digunakan sebagai tempat bersosialisasi. Ketidaksesuaian ada pada jalan utama lingkungan yang tidak memiliki area berjalan kaki secara khusus, dan arus kendaraan yang cukup tinggi.

\section{f. Pedestrian}

Elemen pedestrian tidak memenuhi kesemua aspek yang dibutuhkan untuk mendukung kawasan ramah anak, dengan nilai kesesuaian $0 \%$. Secara umum, maka dapat dikatakan pedestrian yang ada pada sepanjang jalan raya dalam kawasan tidak dirancang untuk anak - anak. Selain itu, pedestrian sepanjang jalan Dr.Moewardi masih belum menjadi satu kesatuan rancangan. Hal ini diindikasikan dengan desain pedestrian yang berbeda satu sama lain ruas jalan. Perbaikan system pedestrian dibutuhkan untuk mendukung kawasan sebagai kawasan ramah anak.

\section{g. Signage}

Elemen signage memenuhi aspek kenyamanan dan stimulasi, sedangkan tidak memenuhi pada aspek keamanan dan kesehatan, sehingga memiliki nilai kesesuaian $50 \%$. Ketidaksesuaian pada aspek keamanan disebabkan tidak adanya signage yang dibutuhkan untuk menjamin keamanan bagi aktivitas anak di kawasan. Hal ini diindikasikan pada aktivitas penyeberangan yang tidak diakomodasi oleh signage penyeberangan yang memadahi. Ketidaksesuaian pada aspek kesehatan disebabkan oleh tidak adanya tanda larangan rokok pada area yang memiliki aktivitas anak di luar sekolah. Tanda larangan hanya berada pada area sekolah.

\section{a. Kesesuaian Berdasarkan Aspek Kawasan Ramah Anak}

Dilihat dari segi aspek keamanan, dari 7 indikator pada setiap elemen rancang didapatkan nilai akhir $2 / 7$ atau $28 \%$. Apabila ditunjukkan dalam bentuk skala, maka tingkat kesesuaiannya mendekati tidak sesuai. Apabila dilihat secara umum, pemenuhan aspek keamanan berprinsip pada kemampuan pengawasan, pencegahan, dan perlindungan. Pengawasan merupakan kemampuan kawasan dalam mengakomodasi pemantauan aktivitas anak - anak oleh orang dewasa dari titik - titik tertentu. Pencegahan merupakan kemampuan kawasan dalam mencegah suatu hal yang membahayakan terjadi pada anak. Sedangkan perlindungan adalah kemampuan kawasan dalam melindungi aktivitas anak dari ancaman luar. Ketiga prinsip ini seharusnya menjadi dasar dalam rencana aksi pembangunan kawasan. Rendahnya tingkat keamanan untuk anak - anak yang beraktivitas dalam kawasan menandakan bahwa secara keseluruhan rancangan fisik kawasan kota barat belum memperhatikan hak anak untuk dilindungi dari segala ancaman.

Dari 7 indikator elemen rancang, aspek kenyamanan terpenuhi $3 / 7$ atau secara persentase adalah $42 \%$. Secara skala rasio, maka dapat dikatakan tingkat kesesuaian dari aspek ini mendekati tidak sesuai. Secara umum pemenuhan aspek kenyamanan berprinsip pada kemampuan memberikan rasa nyaman dalam hal visual, thermal, dan akustik. Dilihat dari indikator yang terpenuhi, rancangan kawasan hanya mampu memenuhi kebutuhan kenyamanan akustik. Tingkat kesesuaian yang mendekati tidak sesuai ini menandakan bahwa secara keseluruhan rancangan fisik kawasan kota barat belum memperhatikan hak anak untuk memperoleh kenyamanan dalam beraktivitas pada suatu ruang. 
Berdasarkan indikator elemen rancang, aspek kesehatan pada kawasan kota barat terpenuhi $5 / 7$ atau secara persentase sebesar $71 \%$. Secara skala rasio, maka dapat dikatakan tingkat kesesuaian dari aspek ini adalah mendekati sesuai. Secara umum pemenuhan aspek kesehatan berprinsip pada pemenuhan kesehatan fisik dan non-fisik atau psikis bagi anak - anak. Berdasarkan indikator yang terpenuhi, rancangan kawasan mampu memenuhi kebutuhan kesehatan secara psikis dengan menjadi pemicu aktivitas yang menyehatkan bagi anak - anak. Tingkat kesesuaian yang mendekati sesuai menandakan bahwa secara keseluruhan rancangan kawasan sudah cukup memperhatikan hak anak untuk dapat beraktivitas pada suatu ruang tanpa terganggu kesehatannya.

Dilihat dari segi aspek stimulasi, terpenuhi 5 dari 7 indikator yang ada dalam kawasan. Secara persentase maka didapatkan angka sebesar $71 \%$. Skala rasio yang didapatkan dari tingkat kesesuaian aspek ini adalah mendekati sesuai. Secara umum pemenuhan aspek stimulasi berprinsip pada stimulasi secara visual dan spasial. Berdasarkan indikator yang terpenuhi, rancangan kawasan mampu memberikan stimulasi secara visual dengan memberikan beragam bentuk dan tekstur. Selain itu secara visual, kawasan tidak memiliki unsur yang memicu anak - anak untuk berbuat yang berbahaya. Tingkat kesesuaian yang mendekati sempurna menandakan bahwa secara keseluruhan rancangan kawasan sudah cukup memperhatikan hak anak untuk memperoleh stimulasi positif bagi perkembangannya.

Berdasarkan aspek - aspek tersebut, aspek keamanan merupakan aspek kawasan ramah anak yang paling kecil nilainya. Ketidakmampuan kawasan dalam memenuhi aspek ini akan mengakibatkan anak - anak berada dalam kondisi yang berbahaya apabila beraktivitas di kawasan ini. Keadaan ini menjadikan aspek keamanan seharusnya menjadi prioritas penanganan dalam membentuk kawasan pendidikan ramah anak. Karena pemberian rasa aman adalah hak dasar yang harus diberikan pada anak - anak.

\section{KESIMPULAN}

Pada dasarnya isu kawasan yang ada dalam kawasan kota barat sebagai pendukung kota ramah anak adalah belum dibentuknya kawasan kota barat sebagai kawasan khusus dengan fungsi utama yaitu aktivitas pendidikan. Keberadaan sekolah dan aktivitas pendukung pendidikan yang mengelompok, disertai pergerakan aktif oleh anak anak di kawasan seharusnya mampu menjadi dasar pembentukan kawasan khusus. Terbentuknya kawasan khusus akan membentuk rancangan kawasan yang lebih terintegrasi dan termonitor dengan lebih baik.

Berdasarkan pembahasan hasil analisis dalam penelitian ini, dapat disimpulkan bahwa tingkat kesesuaian elemen rancang kawasan pendidikan Kota Barat terhadap konsep kawasan ramah anak adalah sebesar $54 \%$. Elemen rancang yang sudah berada pada skala mendekati sesuai adalah tata bangunan dan ruang terbuka. Elemen rancang yang ada pada skala mendekati tidak sesuai adalah tata guna lahan, sirkulasi pergerakan, kualitas lingkungan, pedestrian, dan signage. Secara rinci, hasil analisis kesesuaian setiap elemen rancang terhadap indikator kawasan ramah anak adalah sebagai berikut :

a. Tata Guna Lahan : Mengalami limitasi karena letak kawasan berada di pusat kota dan tutupan lahan pada lahan sekolah yang tergolong tinggi.

b. Tata Bangunan : Elemen tata bangunan sudah sesuai dengan indikator kawasan ramah anak.

c. Sirkulasi : Adanya jalur dua arah yang berarus tinggi yang bersinggungan langsung dengan akses sekolah dan tidak adanya jalur khusus untuk sirkulasi anak.

d. Ruang Terbuka : Tidak mendukung fungsi pengawasan karena aktivitas pedagang yang menutupi pandangan ke dalam.

e. Lingkungan: Vegetasi yang masih belum memenuhi kebutuhan dalam membentuk karakter kawasan dan ketidakmampuan jalan sebagai tempat bersosialisasi. 
f. Pedestrian : Pedestrian tidak memenuhi kesemua aspek karena pedestrian tidak dirancang menjadi satu sistem dengan konsep ramah anak.

g. Signage : Tidak adanya signage yang menjamin keamanan anak, dan tidak adanya signage yang menjamin kesehatan anak.

Ditinjau dari aspek kawasan ramah anak, aspek keamanan memiliki nilai kesesuaian terendah dengan nilai $28 \%$. Keamanan berprinsip pada kemampuan pengawasan, pencegahan, dan perlindungan. Selain itu, terwujudnya rasa aman juga menjadi salah satu prioritas hak anak yang perlu untuk dipenuhi dalam segala aktivitas anak-anak. Tidak terpenuhinya ketiga prinsip tersebut menjadikan aspek keamanan perlu untuk menjadi prioritas pembangunan Kawasan Kota Barat.

Secara umum, dilihat berdasarkan tahapan dalam menuju kota ramah anak, Kota Surakarta seharusnya telah melalui tahap penyertaan hak anak pada strategi dan rencana aksi pembangunan. Namun hasil analisis menunjukkan rancangan kawasan kota barat masih belum sesuai dengan kriteria kawasan ramah anak. Perlu adanya peninjauan ulang pada rencana aksi, khususnya yang ada pada kawasan kota barat untuk menjadikan kawasan kota barat sebagai kawasan ramah anak.

Rekomendasi yang bisa diberikan atas penelitian ini adalah pembentukan kawasan khusus Kota Barat sebagai kawasasn dengan fungsi utama sebagai kawasan pendidikan, hal ini akan memudahkan integrasi aktivitas, monitoring, dan evaluasi terhadap program Kota Layak Anak. Prioritas pembenahan rancangan kawasan pada pedestrian sebagai system prasarana yang mendukung pergerakan aktif antar pusat aktivitas juga diperlukan, karena pedestrian menjadi salah satu elemen yang mampu mengintegrasikan setiap pusat aktivitas. Terakhir, pembentukan lembaga atau organisasi khusus yang bertanggung jawab akan kegiatan anak dan pemenuhan hak anak juga dibutuhkan untuk menjadi pengawas dan penggerak dalam perumusan kebijakan kota.

\section{DAFTAR PUSTAKA}

\section{Buku}

Shirvani, H. (1997). Urban Design Process. Michigan: Van Nostrand Reinhold Company.

Sugiyono. (2013). Metode Penelitian Kuantitatif, Kualitatif, dan R\&D. Bandung: Alfabeta.

\section{Jurnal}

Andryana, S. (2009). Analisa Faktor - Faktor yang Mempengaruhi Pemilihan Sekolah Dasar di Kota Depok menggunaka Metode Proses Anaisa Bertingkat. Jurnal Basis Data, ICT Research Center UNAS, 29-42.

Arikunto. (2011). Prosedur Penelitian suatu Pendekatan Praktik. In T. Taniredja, \& H. Mustafidah, Penelitian Kuantitatif Sebuah Pengantar (p. 48). Purwokerto: Alfabeta.

Audrey, S., \& Batista-Ferrer, H. (2015). Healthy Urban Environments for Children and Young People : A Systematic Review of Intervention Studies. Health and Place, 97-117.

Diyanti, A. O. (2014). Lingkungan Ramah Anak pada Sekolah Taman Kanak-Kanak. Jurnal RUAS, Volume 12 No 2.

Lam, T. H., Chung, S. F., Betson, C. L., Wong, C. M., \& Hedley, A. J. (1998). Strongest Risk Factors for Smoking in Hong Kong Students. American Journal of Preventive Medicine, 217-223.

Malone, K. (2013). "The Future Lies in Our Hands" : Children as researchers and environmental change agents in designing a child-friendly neighbourhood. Local Environment, 372-395.

Nour, O. H. (2013). Building Child Friendly Cities in the MENA Region. Int Rev Educ Vol.59, 489-504. 
Nurkancana, \& Sumartana. (2011). Penelitian Kuantitatif sebuah Pengantar. In T. Taniredja, \& H. Mustafidah. Purwokerto: Alfabeta.

Rothman, L., Howard, A., Buliung, R., Macarthur, C., Richmond, S., \& Macpherson, A. (2016). School Environments and Social Risk Factors for Child Pedestrian - Motor Vehicle Collisions : A Case-Control Study. Accident Analysis and Prevention, 252-258.

\section{Jurnal yang diakses Online dengan nomor DOI atau URL}

Alfindasari, D. (2014, 11). Teknik Analisis Data : Statistik Deskriptif. Retrieved from Eureka Pendidikan: www.eurekapendidikan.com/2014/11/teknik-analisis-data-statistik.html

\section{Ensiklopedia atau Buku Referensi lainnya}

UNICEF. (2006). The Child Friendly School Manual. Retrieved from UNICEF South Africa: http://www.unicef.org/publications/files/Child_Friendly_Schools_Manual_EN_040809.pdf Times, 12/12/2005, p.4.

\section{Dokumen Pemerintah yang Tersedia Online}

Badan Pusat Statistik. (2010). Teknik Analisis Statistik. Retrieved from Badan Pusat Statistik: www.bps.go.id

BAPERMAS Kota Surakarta. (n.d.). Wujudkan Kota Surakarta sebagai Kota Layak Anak. Retrieved from Pusat Informasi Kota Surakarta: http://www.surakarta.go.id/konten/wujudkan-kota-surakarta-sebagai-kota-layak-anak

\section{Dokumen Pemerintah}

Kementerian PU. (2007, Maret 16). Pedoman Umum Rencana Tata Bangunan dan Lingkungan. Peraturan Menteri Pekerjaan Umum Nomor 06/PRT/M/2007. Indonesia.

Soebagiyo, D. (2007). Penentuan Kompetensi Produk Inti Daerah di Kota Surakarta. Surakarta: Pemerintah Kota Surakarta. 